\title{
The Content Analysis Of English Workbook Used In Smkn 1 Gombong
}

\author{
Dwi Wiji Astuti \\ English Education Department ,Faculty of Teacher Training and Education \\ Mercu Buana University of Yogyakarta \\ email: widwi.astuti30@gmail.com
}

\begin{abstract}
The research belongs to content analysis which focused on analyzing English workbook content used for grade ten in SMKN 1 Gombong. In analyzing the workbook, the researcher considered the five aspects of standardized book suggested by Hutchinson and Waters (2003): audience, aims, content, methodology, and other criteria. The objective of this research was to find out the quality level of English workbook content based on the criteria of standardized book proposed by Hutchinson and Waters (2003). The instruments used in this research were interview, observation, and documentation. The researcher applied both qualitative and simple quantitative method for this research. Qualitative was used for analyzing and delivering the result into depth description; meanwhile, simple quantitative was for computation result of analysis in a form of number. Based on the result of the research, the workbook was in the fair level, also the researcher viewed that the workbook included into a less standardized book. It was proven by the total scoring of analysis that the workbook reached the number of 35. After doing analysis, the workbook used for grade ten in SMKN 1 Gombong contains of General English.
\end{abstract}

Keywords: English workbook, competence, standardized book, content analysis.

\section{Introduction}

Workbook is the common media used in many schools. Based on Depdiknas (2004), workbook is usually in a form of guideline, the ways to answer the questions, and an exercise has clear basic competences as goals. Since Indonesia treats English as the foreign language, the use of media is essentially needed. There are many kinds of high school in Indonesia; senior high school, vocational high school, also Islamic high school. The definitions of three kinds of high schools come from Peraturan Pemerintah

Nomor 66 Tahun 2010 which define senior high school as one of formal education that holds general education in secondary level as a continuation of junior high school; Islamic high school is one of formal education guided by Minister of Religion that focuses on general education with religious particularities in secondary level as continuation of junior high school; whereas, vocational high school emphasizes on vocational education in secondary level as continuation of junior high school. Different from other schools, vocational high school highlights more on preparing the students for upcoming jobs. Therefore, it offers several majors for the students such as accounting, engineering, automotive, tourism, and broadcasting. For that reasons, the teacher of this school should adapt the learning objectives with the student's major because they learn in certain field and need to know English materials related to their field. In vocational high school programs which are also known as career and technical education programs, students study a skill or trade such as engineering or plumbing, in addition to completing academic core requirements 
(Pannoni, 2014). Connecting to those words, the English teacher has to prepare the teaching and learning process well by selecting the appropriate both textbook and workbook.

Considering the important of English for Specific Purpose (ESP) for vocational students, the teacher should be careful in choosing media also assessment instruments. One of the assessment instruments teacher may use is workbook. By using workbook, teacher can measure the students' understanding toward the material given. In this case, the teacher needs a good skill to choose which the English workbooks will be used for the students. A good workbook based on Hutchinson and Waters should cover some aspects such as target needs, aims of the material, content of the book, methodology used, and other criteria.

Nowadays, many publishers in Indonesia provide various workbooks in order to help the teachers assessing their students. Based on the last three years (2013 to 2015) statistics from Indonesian Publishers Association (IKAPI, 2015), the number of publishers in Indonesia is always increasing. There were 1228 publishers in 2013, 1309 in 2014, and 1.328 in 2015. In fact, the publisher does not really recognize what exactly the needs of both teachers and learners, and simply make the English workbook based on the current curriculum. Educational publisher frequently yet not in all instances look for materials that suit the widest possible audience, no matter what they consist of audio, video, or computer software to fit the hardware; hands-on materials such as charts, wallboards, workbooks, paste-on, etc.; along with all the other types that have two conventional covers (Dubin and Olshtain, 1990, p.167).

Therefore, evaluating English workbook is needed to do in order to get information about the content and quality of it. Evaluation is a matter of judging the fitness of something for a particular purpose. It concerned with relative merit and there is no absolute good or bad - only degrees of fitness for the required purpose (Hutchinson and Waters, 2003, p.96). Davies and Pearse (2002) add that evaluation is measuring of strengths and weaknesses.

In addition, Hutchinson and Waters define that a good book should fulfill several criteria. There are five criteria of the standardized book which will be used to analyze; audience, aims, content, methodology, and other criteria. Later, each criterion has some features in it. After knowing those criteria, the researcher intended to analyze the English workbook used in SMKN 1 Gombong. There was a problem occurred related to English language teaching in this school. The researcher found it in a previous observation. The English teacher taught the students only by using the workbook as the main media and assessment tool in teaching-learning process. For that reason, the researcher chose SMKN 1 Gombong as the research setting in order to know the workbook content quality by evaluating it, whether it was General English or English for Specific Purposes. The 
workbook used in this school was entitled "Victory". It provided both the texts and questions based on the current curriculum and it was addressed for the students in the first grade of secondary level. The researcher analyzed the workbook content using the standardized book criteria suggested by Hutchinson and Waters (2003). It is conducted to find out the data of the workbook whether the content is General English or English for Specific Purposes (ESP).

\section{Research Method}

Dealing with workbook analysis, this research was categorized as document analysis or content analysis since the data of this research was in the form of document; that was the English workbook entitled "Victory" used for grade ten. Hall (2001) says content analysis is a research technique for systematically analyzing written communication. In this research, written communication was in the form of English workbook. Concerning on the research method, the researcher combined between qualitative and simple quantitative methods. Qualitative was used for the content analysis process and simple quantitative method to present the totaling scores of analysis.

The data of this research was in the form of workbook entitled "Victory" used in tenth graders of SMKN 1 Gombong. It was distributed and printed by Penerbit T71 and the author is R. Aryanti Virna S.S. It contains of texts and exercises based on the 2013 Curriculum. As the other workbooks, the "Victory" workbook for grade ten focuses on giving more exercises which are expected to help the students in understanding the topics.

Several instruments were used for conducting this research such as interview, observation, and documentation. Then, the researcher did several steps like having interview with the English teacher, observation in the class, distributing questionnaire, analysis the workbook content, and studying the analysis result as stated in Chart 1.

Chart 1: Procedures in this research

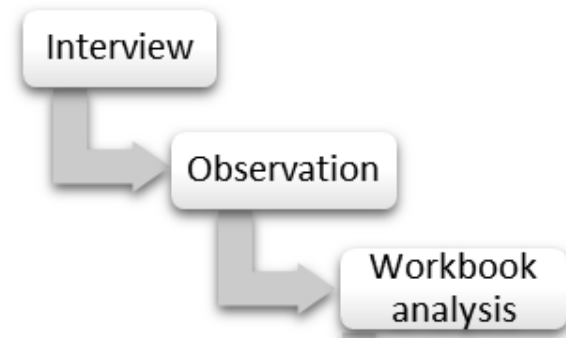

analysis

Study of

the result

The first step in this research was interview. The researcher did the interview with the English teacher in SMKN 1

Gombong. It was done in order to gain the 
information and data of English syllabus used there. In conducting the interview, the researcher used the guided questions to ease the process of gathering the data.

Referring to the second step, it dealt with observation. This step was conducted to check the given information with the actual condition in a class. In doing the observation, the researcher used a logbook as the tool to help the documentation. The logbook contained the lists of what the researcher has to observe.

The third step was analysis the content of the workbook. The researcher analyzed the content of "Victory" workbook which is used for grade X of secondary school level. In analyzing the workbook, the researcher used the five criteria of standardized book suggested by Hutchinson and Waters (2003). The researcher answered the questions which belongs to objective analysis, since this research focused on analyzing or evaluating the content of the workbook.
On the last step, the researcher studied the analysis result. It means that the researcher gave judgment to the result of the analysis whether the workbook fulfilled the criteria of standardized book suggested by Hutchinson and Waters or not.

Then, the researcher evaluated the content of the workbook by giving point 0,1 , and 2 on each feature (Hutchinson and Waters, 2003, p. 104). 0 is for the data that does not match the desired feature; 1 is for the data partly matches the desired feature; and 2 is for the data closely matches the desired feature. The computation used the formulation as follows:

$$
\text { Score }=\frac{\left(\sum x: 2\right)}{n} \times 100
$$

$\sum \mathrm{X}$ : total points of all features (divided

2)

n : total features

Categorization:

Table 1. Categorization

\begin{tabular}{cc}
\hline Score & Categorization \\
\hline $76-100$ & Very good \\
$51-75$ & Good \\
$26-50$ & Fair \\
$\leq 25$ & Poor \\
\hline
\end{tabular}

\section{Findings and Discussions}

This workbook analysis involved the five criteria of standardized book proposed by Hutchinson and Waters (2003) namely audience, aims, content, methodology, and other criteria.

\section{Audience}

The first criteria which belongs to objective analysis for evaluating the book is 
the audience. In this case, audience means the students or learners who use the book and it deals with the information of the book intended for. Concerning on this aspect, English workbook entitled "Victory" is intended for the students in grade ten of SMA/MA/SMK/MAK and it implements the 2013 Curriculum. The "Victory" workbook was designed as a media in teaching English for all kinds of high school level. In SMKN 1 Gombong as the research setting, teacher used this workbook as the media for teaching English for grade ten. The students in grade ten are in the range of 15 to 16 years or teenager learners. They are from five different majors in SMKN 1 Gombong, like multimedia, networking, automotive, engineering, and motorcycle technical. All of them used the same English workbook for learning English.

\section{Aims}

The author of the "Victory" workbook said that the workbook was designed as the supporting media in improving student's competence and characters building. The aims of the workbook based on the author's statement are actually appropriate with the 2013 Curriculum teaching goals. In fact, the content of workbook did not truly concern on the teaching-learning objectives of 2013 Curriculum. Related to the improving student's competence and characters building, the materials in "Victory" workbook did not present any text which worked for those two things. Firstly, it was proven by looking at the speaking activities in the workbook, whereas the students should do the monotonous speaking exercises; practiced the given dialogues. The researcher viewed that it could not help the students to improve their speaking skill. Secondly, the workbook contains only a few of characters building texts and it was available simply in certain topic: Expressing Sympathy. Therefore, the workbook content was not appropriate with the 2013 Curriculum requirements.

\section{Content}

Content deals with some features such as the language points, proportion of skills, micro-skills, kinds of texts, subject-matter areas and treatment of the topics given, and content organization. Speaking of language points, the "Victory" workbook performs many grammar exercises for the students; meanwhile, it did not provide any space containing pronunciation and vocabulary area in each topic. For the proportion of skills, almost exercises in the workbook consist of integrated skills such as listening and speaking, listening and writing, then reading and writing. However, those macro skills in "Victory" workbook merely fulfilled a few number of micro skills lists. The researcher used the micro skills lists adapted from Richards (1983).

The "Victory" workbook contains of many exercises in it and kind of texts mostly found in the workbook are in the form of short conversation between two people. The other texts could be found in the workbook were letters, articles, descriptive texts, 
narrative texts, announcements, and song lyrics. Therefore, the researcher viewed that the "Victory" workbook performed enough kinds of texts for the students. The workbook was used by the students of grade ten in SMKN 1 Gombong whereas they are from five different majors like engineering, multimedia, networking, automotive, and motorcycle technical. The researcher thought that there was an inexpediency occurred in this case between the content of the workbook and the subject matter areas. The researcher did not find any texts and materials in the workbook which could cover to one of those majors. Then, the topics are presented in a straightforward manner. It was showed by the presentation of topics in the workbook, where the students were given many exercises based on the topics. There were several topics which did not have any explanation in the beginning, so the students just did the activities directly.

In the workbook, the content was in the form of activities, then it was set based on the English study skills. All topics in the workbook had the same organization of exercises which started from listening to writing skills. Nevertheless, most of contents were not in a good order related to the difficulty level. Concerning on the content sequenced within a unit, it could not be used to explore more the student's ideas. It was shown by the activities presented in the workbook. Most of writing skill activities asked the student's to complete the blanks by using the available answers in the box. The same case happened in speaking exercises where the students had to work in pairs in order to act out the given conversations. Those activities were included to guided exercises; meanwhile, the "Victory" workbook did not provide the free exercises.

\section{Methodology}

Methodology aspect has seven features which deals with the theory of learning, expectation of learning English based on the materials, kinds of exercises, teachinglearning techniques, aids, provided guidance, and material flexibility. The first feature discusses theory of learning used in the book. The "Victory" workbook implements the 2013 Curriculum which demands both cognitive and affective domain. Yet, the workbook simply concerns on the student's cognitive domain. Relating to the second feature, expectation of learning English, it was not stated in workbook clearly and explicitly by the author. It could be proven by looking at the materials in the workbook, then there was no learning objectives detailed. In this circumstance, the researcher could catch what actually the author expectation towards the materials. The author wanted to familiarize the students with English through the English conversations, since most of exercises presented in the workbook were in the form of conversations.

The third feature is about kinds of exercises presented in the workbook. The researcher found that the "Victory" workbook was one of workbooks which provided several kinds of exercises such as completing the gaps/sentences, arranging 
disorder words/sentences, grammar exercises, answering the questions based on reading text, and practicing the dialogues. The weaknesses are speaking activities only has a kind of activity in 11 topics, and generally activities in the workbook included into guided exercises.

Concerning on the forth feature, teaching learning techniques, the workbook has two various techniques for students in doing exercises; individual and pair-work techniques. Mostly, the researcher found that the workbook demanded the students to do the exercises individually. It was showed by the amount of the exercises where the individual work was more than pair-work techniques. Pair-work technique was only used in speaking exercises that the students needed to practice the conversations with their partner.

Referring to the fifth feature, it deals with aids which can be used to deliver the materials. The exercises that required media a lot were in the listening section, because many listening activities asked the students to listen and fill the blanks about dialogues, songs, monologues, and radio announcements. Since the "Victory" workbook mostly used the guided exercises, the materials require the aids only on listening sections.

The sixth feature talks about the provided guidance in the workbook. It means the things used to support the teaching and learning process, such as statement of aims, list of vocabulary and language-skills point, language guidance, technical information, hints, suggestions for further work, and test. The evaluation object is the "Victory" workbook which contains of many English activities for the students. In the beginning of each topic, the researcher could not find any statement of learning aims. In the same way, there was no clear statement of aims listed in the "Victory" workbook. The guidance existed in the workbook purely in the form of instructions before the exercises. It used to lead the students in understanding what they should do with the exercises.

The last feature is material flexibility. The researcher viewed the teacher could not begin to use the material in the workbook at different point. It happened because the author arranged the topics in well-ordered based on the analysis of core and basic competences/English syllabus. Therefore, the teaching-learning process using the "Victory" workbook should be started from the beginning to the end of the book in order to follow the syllabus. By analyzing the content, it could not be linked to other subject materials. It only contains of the materials which discuss English in general context. The "Victory" workbook used for five majors in SMKN 1 Gombong, but there was no materials which could be linked to one of the majors. For that reasons, the researcher could say that the workbook not flexible as well.

\section{Other Criteria}

Other criteria deals with the price and the way to obtain the book. The price of 
"Victory" workbook was affordable and it could be proven by the result of observation and interview with the English teacher that all students of grade ten in SMKN 1 Gombong had this workbook. Based on the interview section, the teacher said that all students bought the workbook were not because of their obligation. They still could read and borrow the book freely since the school provided it in the library. The workbook "Victory" was easily to get because the students could find it in the school library, then for those who wanted to have it could contact their English teachers.

\section{Conclusion}

The objective of this research was to evaluate the English workbook entitled "Victory". It is used by vocational high school students in grade ten and it adapts the 2013 Curriculum. The researcher analyzed the workbook by using the five criteria of standardized book suggested by Hutchinson and Waters (2003). Those five criteria are audience, aims, content, methodology, and other criteria. Based on the result of this research, the "Victory" workbook was in the fair level, also the researcher views that the "Victory" workbook is a less standardized book. It was proven by the total of scoring of analysis that the workbook reached the number of 35. After doing analysis, the materials in workbook included to General English.

\section{Recommendation}

Based on the result of the research, there are recommendations which can be offered to English teachers, school policy makers, and other researchers. Firstly, the teachers should be more careful in choosing the workbook. It would be better if the teachers evaluate the workbook first, before using it to teach. It has to do in order to make sure the students learn English materials appropriately. Secondly, the school policy makers should publish a new policy dealing with providing the standardized English workbook. The school policy maker as a decision maker has to know the quality of the book before it is being used for the vocational high school students. Last, the other researchers may use the result of this research as one of the considerations in starting the research dealing with the content analysis of workbook.

\section{References}

Davies, P. and Eric Pearse. 2002. Success in Teaching English. Oxford: Oxford University Press.

Departemen Pendidikan Nasional. 2004. Pedoman Umum Pengembangan Bahan Ajar Sekolah Menengah Atas. Departemen Pendidikan Nasional, Direktorat Pendidikan Menengah Umum.

Dubin, Fraida and Elite Olshtain. 1990. Course Design; Developing programs and materials for language learning. Cambridge: Cambridge University Press.

Hall, Shane. 2001. How to Do Content Analysis. Available from http://classroom.synonym.com/content -analysis-2670.html. [Accessed: 28 November 2015].

Hutchinson, Tom and Alan Waters. 2003. English for Specific Purposes; A Learning-centred approach. Cambridge: Cambridge University Press. 
IKAPI. 2015. Buku Indonesia Dalam Angka. Available from www.ikapi.org/statistik. [Accessed: 23 February 2016].

Pannoni, Alexandra. 2014, October 20. Vocational High School Programs an Option for Teens. Available from http://www.usnews.com/education/blo gs/high-school- notes/2014/10/20/vocational-highschool-programs-an-option-for-teens. [Accessed: 19 November 2015].

Peraturan Pemerintah Republik Indonesia Nomor 66 Tahun 2010 tentang Perubahan Atas Peraturan Pemerintah Nomor 17 Tahun 2010 tentang Pengelolaan dan Penyelenggaraan Pendidikan. 